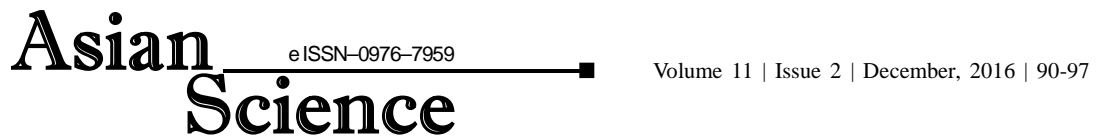

\section{Process standardization of low sugar, low calorie and fibre enriched Lal Peda}

\author{
B.C. ANDHARE*, D.C. RAI AND TANWEER ALAM ${ }^{1}$ \\ Banaras Hindu University, VARANASI (U.P.) INDIA
}

\begin{abstract}
Varanasi,the city of gallis and ghats is not only famous for its Banarasi saree and Banarasi paan, but also famous for the Lal Peda loaded with higher amount of sugar and loaded with ghee, the Peda is shaped by hand and dusted with semolina and pistachios as a finishing touch. LalPeda is a popular heat desiccated traditional dairy delicacy of eastern India specially Uttar Pradesh. It is prepared by blending of Khoa and sugar followed by heat desiccation until characteristic reddish brown colour appears. The Lal Peda is deficit in fibre so the developed Lal Peda was prepared with addition of oat. This product is manufactured since long time yet not glamorized as other Khoa based sweet products like Burfi, Peda etc. The main reason behind this is, these products centered into specific areas and have not proper focused by research scientists and extension workers. So the experiment was carried out on low calorie, low sugar and fibre enriched Lal Peda. The process for the manufacture of low calorie, low sugar and fibre enriched Lal Peda was standardized. Optimization of product stages and levels of addition of maltodextrin, sorbitol, oat, sugar and aspartame were used with help of sensory evaluation score. Hence, the formulation with buffalo milk with 3 per cent fat, 2 per cent maltodextrin, 0.50 per cent oat on the basis of milk and 20 per cent sugar and 0.10 per cent aspartame on the basis of Khoa were considered to be the most appropriate formulation for preparation of low sugar, low calorie and fibre enriched Lal Peda. The proximate composition of developed Lal Peda contained 17.95 per cent moisture, 14.28 per cent fat, 16.93 per cent protein, 13.58 per cent lactose, 20.18 per cent sugar, 3.18 per cent ash and 4.18 per cent dietary fibre. Preliminary studies were carried out for screening of fat replacers i.e. maltodextrin and sorbitol for replacement of fat. Then various stages like at milk stage, at Rabri stage and lastly at pat formation stage for addition of fat replacers were analyzed. As the developed Lal Peda was enriched with fibre, oat was used. The stage of addition and various levels were also analyzed. The developed low calorie and fibre enriched Khoa was used for preparation of Lal Peda. For preparation of Lal Peda, various levels of sugar and aspartame as sugar replacement was used. The selection of various stages and levels, the sensory evaluation by semi expert judges was carried out. The developed Lal Peda was finalized by screening method.
\end{abstract}

Key Words : Low sugar, Low calorie, fibre, Lal Peda, Process standardization

View point paper : Andhare, B.C., Rai, D. C. and Alam, Tanweer (2016). Process standardization of low sugar, low calorie and fibre enriched Lal Peda. Asian Sci., 11 (2): 90-97, DOI : 10.15740/HAS/AS/11.2/90-97.

\footnotetext{
* Author for correspondence

B.C. Andhare, College of Agriculture, Badnapur, Jalna (M.S.) INDIA (Email: andharebcshree@ gmail.com)

${ }^{1}$ Tanweer Alam, Indian Institute of Packaging, NEW DELHI, INDIA
} 